\title{
Judge me, judge me not: The role of eye size and observer gender on acquaintance rape
}

\author{
Maria Clara Ferrão ${ }^{1 *}$, Gabriela Gonçalves ${ }^{1,2}$, Jean Christophe Giger ${ }^{1}$, Tiago Parreira ${ }^{1}$ \\ ${ }^{1}$ University of Algarve (Portugal). \\ ${ }^{2}$ Research Centre for Spatial and Organizational Dynamics (Portugal).
}

\begin{abstract}
Título: Júzgame, no me juzgues: el rol del tamaño ocular y el género del observador en la violación por un conocido

Resumen: El propósito de este estudio fue examinar el efecto del tamaño ocular y el género del observador en la atracción inicial percibida, honestidad, y atribuciones de responsabilidad en la violación. Se probó un diseño experimental 3 (tamaño del ojo: pequeño vs. normal vs. grande) x 2 (género del observador: masculino vs. femenino). Noventa participantes (45 mujeres y 45 hombres) observaron una de tres caras femeninas asignadas al azar (con manipulación del tamaño de los ojos), y puntuaron la honestidad y atractivo inicial. Entonces se les pidió que leyeran un escenario de violación por conocido con una mujer tradicional, puntuando la responsabilidad de la víctima y del agresor. Se demostró que el tamaño del ojo afecta a todas las variables del estudio: el rostro femenino con ojos grandes fue visto como más atractivo y honesto, se consideró menos responsable de su propia victimización, y el delincuente se vio como más responsable. El género se ha demostrado que afecta a la percepción de atracción inicial y a la responsabilidad de la víctima. Se discuten las implicaciones teóricas y prácticas

Palabras clave: Violación por un conocido; tamaño de los ojos; género del observador; atribución de responsabilidad; atractivo; honestidad.
\end{abstract}

\section{Introduction}

The phenomenon of rape is a widely occurring crime with no cultural boundaries (Grubb \& Turner, 2012). Unlike other crime victims, sexually victimized women are often stigmatized and judged as being responsible for their own fate (Angelone, Mitchell, \& Lucente, 2012; Grubb \& Turner, 2012; Krahè, 1991; Rebeiz \& Harb, 2010). These common misconceptions are part of a long-tradition of blaming that keeps the victims from reporting the crime (Gregory \& Lees, 1999; Kelly, 2002). The social stigma attached to this sort of crime is higher in acquaintance rape: as the sexual assault is committed by someone known to the victim, there is a common misconception that she has somehow triggered the situation. It is also believed that this is not as serious or traumatic to the victim as stranger rape (Abrams, Viki, Masser, \& Bohner, 2003; Gerdes, Dammann, \& Heilig, 1988; Gölge, Yavuz, Müderrisoglu, \& Yavuz, 2003; Viki \& Abrams, 2002).

A large body of literature has examined a number of variables which are likely to influence the stigma attached to rape perception. This is thought to be explained by a plethora of personal, psychological and situational factors, including the victim and the perceiver personal characteristics. Observers are subject to biased perspectives based on their own beliefs and unique characteristics (e.g., gender, race, and empathy), as well as on the victim's attributes (e.g., physical traits, sexual history, and behaviour) (Angelone et al., 2012;

* Dirección para correspondencia [Correspondence address]: Maria Clara Ferrão. University of Algarve. Faculdade de Ciências Humanas e Sociais. Campus de Gambelas. CP 8005-139, Faro (Portugal). Email: mctferrao@gmail.com

\begin{abstract}
The purpose of this study was to examine the effect of eye size and observer gender on perceived initial attraction, honesty, and attributions of responsibility for rape. A 3 (eye size: small vs. normal vs. large) x 2 (observer gender: female vs. male) experimental design was tested. Ninety participants (45 women and 45 men) observed one of three randomly assigned female faces (with eye size manipulation), and rated initial attraction and honesty. They were then asked to read an acquaintance rape scenario with a traditional woman, rating the victim and perpetrator responsibility. Eye size was shown to affect all the study variables: the female face with large eyes was seen as more attractive and honest, was held less responsible for her own victimization, and the offender was held more responsible. Gender was proven to affect perceived initial attraction and victim responsibility. Theoretical and practical implications were discussed.

Key words: Acquaintance rape; eye size; observer gender; attributions of responsibility; attraction, honesty.
\end{abstract}

Gölge et al., 2003; Grubb \& Harrower, 2009; Grubb \& Turner, 2012; Pollard, 1992).

The face is the most exposed and visual feature of one's identity, with the eyes as its central focus (Argyle, 1970; Geldart, Maurer, \& Carney, 1999), and the group membership of individuals (e.g., based on gender) (Tajfel, Billig, Bundy, \& Flament, 1971; Tajfel \& Turner, 1986) affects social perception. Therefore, research on these basic aspects of interpersonal relations emerges as a pathway to gain knowledge about the process of judging others. It further supports intervention programs aimed at reducing erroneous beliefs about rape victims within social and legal contexts (Anderson \& Whiston, 2005; Grubb \& Harrower, 2009).

Considering the role of facial traits in social perception and the biased beliefs regarding rape victims, the main purpose of this study is to examine the effects of the victim (eye size) and observer characteristics (gender) on attributions of responsibility for rape.

\section{From physical appearance to eye size}

As individuals attempt to reduce a complex stimulus world to a controllable level, they tend to make evaluative and moral judgments based on physical appearance (Ambady \& Skowronski, 2008; Atoum \& Al-Simadi, 2000). When meeting someone for the first time, social observers focus their attention on the most immediate characteristics to make inferences (Dion, Berscheid, \& Walster, 1972). Physical appearance (along with sexual identity) is one of those characteristics, thus influencing perceptual processes and causing a dyadic relationship between physical cues and the inference of personality traits. This association is reflected on the belief that "what is beautiful is good" (Dion et al., 
1972), leading to cognitive and motivational biases that see attractive people as more likeable and socially adjusted.

The above-mentioned biases are closely related to initial attraction, a concept that defines a positive attitude and a predisposition to interact with others from an early moment (Rodrigues \& Garcia-Marques, 2006). Initial attraction is characterized by the willingness to interact/positivity (positive feelings towards someone and disposition to interact with him/her from the first moment), physiological reactions (level of arousal experienced by a person towards another), and flirting/fantasizing behaviours (a pattern of thought that stirs one's imagination and sexuality towards someone) (Rodrigues \& Garcia-Marques, 2006). Overall, the influence of biological and cultural factors leads to a greater disposition to experience attraction for the opposite gender (Griffin \& Langlois, 2006; Rodrigues \& Garcia-Marques, 2005).

The preference for attractive people occurs at an early stage of human development: even children prefer to look at attractive faces (Langlois, Ritter, Roggman, \& Vaughn, 1991; Rubenstein, Kalakanis, \& Langlois, 1999). Therefore, attraction appears to be a facilitator of interpersonal relationships, given that attractive people are considered more professional, sociable, competent, popular (for a review, see Langlois et al., 2000), intelligent (Moore, Fillippou, \& Perrett, 2011), honest (Shinners 2009), and sexually desirable (Dion et al., 1972). This positive bias also affects behaviour, in that attractive individuals receive more attention, elicit pro-social behaviours (e.g., help), and experience less punishment than their unattractive counterparts (Langlois et al., 2000).

Different experimental studies using hypothetical rape scenarios have further reported the same sort of biases within rape contexts (e.g., Deitz, Littman, \& Bentley, 1984; Gerdes et al., 1988; Tarsi \& Jalbert, 1999). Inferential processes regarding rape are likely to be influenced by physical attributes: unattractive victims are held more responsible for sexual assault (Deitz et al., 1984; DeJong, 1999; Gerdes et al., 1988; Seligman, Brickman, \& Koulack, 1977; Thornton \& Ryckman, 1983; Vrij \& Firmin, 2001), are seen as less honest and trustworthy (Vrij \& Firmin, 2001), and activate negative feelings and rejection (Deitz et al., 1984; Thornton \& Ryckman, 1983). Moreover, the evidence against the offender is considered weaker (Vrij \& Firmin, 2001) and he is assigned shorter prison sentences, suggesting that rape against unattractive women is taken less seriously (Feild, 1979).

On the other hand, as attractive victims are more likely to receive sympathy, they are perceived as more honest and less responsible for their own victimization, whereas the offender is held more responsible (Vrij \& Firmin, 2001). Honesty, defined as the act of communicating and acting truthfully (Reysen, 2008), is more influenced by nonverbal cues (e.g., physical traits) than by verbal cues. The perception of honesty based on nonverbal cues, such as appearance and gender, may therefore lead to the occurrence of attribution errors and less precise judgments (Shinners, 2009).
The explanation for the evidence reported is not immediate: on the one hand, unattractive victims may be blamed for the attack because they are seen as unlikely targets, which may mean that they encouraged or provoked the situation (Deitz et al., 1984, DeJong, 1999; Krahè, 1991); on the other hand, the occurrence of positive feelings towards attractive victims may elicit a greater desire to support the victim and to punish the offender (Erian, Lin, Patel, Neal \& Geiselman, 1998). Whatever the reasons, the social advantages of attractive individuals may be explained by the halo effect, whereby the perception of one trait affects the perception of other traits (Shinners, 2009).

In the context of social perception, when we judge others by physical appearance we tend to focus on the facial features (Atoum \& Al-Simadi, 2000). The face is the main channel of interpersonal communication and comprises several morphological elements (Kościński, 2007), particularly the eyes, which are the primary centre of the face (Argyle, 1970). In a study using static facial images (with a female stimulus), Geldart and colleagues (1999) have shown that the eye size affects visual fixations of five-month-old babies, as well as aesthetic judgments of adults, which suggests their preference for larger facial features.

Baby-faced adults (particularly with larger eyes) are usually believed to have more socially desirable traits: they are considered more attractive and sociable (Cunningham, Roberts, Barbee, Druen, \& Wu,1995; Geldart et al., 1999; Gonçalves et al., 2012a, 2012b, 2014; Pettijohn \& Tesser, 2005), honest, caring, empathetic, and intelligent (Atoum \& AlSimadi, 2000; Paunonen, Ewan, Erathy, Lefave, \& Goldberg, 1999). However, the effect of eye size on rape perception is not clearly defined.

It is also noteworthy that traditional women, typically represented by housewives, are deemed to possess more positive traits than non-traditional women, in part due to the perception of attributes such as kindness and warmth (Capezza \& Arriaga, 2008; Fiske, Cuddy, Glick, \& Xu, 2002). Women are expected to act appropriately and not to precipitate their own victimization: if they adopt behaviours such as provocativeness, the interpretation of a rape situation may become less than factual and centred on the victim's character (Best \& Demmin, 1982).

\section{The influence of observer gender on rape perception}

The literature regarding the effect of observer gender on the perception of sexually victimized women shows conflicting data. In some studies, observer gender was shown not to influence the attributions of responsibility for rape (e.g., Acock \& Ireland, 1983; Gerdes et al., 1988; Krahè, 1988; Johnson, Jackson, \& Smith, 1989). Most of the studies, however, report gender differences, showing that men have less positive attitudes towards the victim and hold her more responsible for the crime (e.g., Cohn et al., 2009; Deitz et al., 1984; Gölge et al., 2003; Whatley, 2005; Workman \& Freeburg, 1999). Some authors even report that women are more 
likely to blame the victim, at least under certain conditions (e.g., Luginbuhl \& Mullin, 1981; Nagel, Matsuo, McIntyre, \& Morrison, 2005).

In fact, most of the research on rape perception identifies significant differences in how women and men evaluate situations involving sexually victimized women. In general, men have more stereotypical beliefs about the sexual assault, perceiving rape as a sexually motivated crime (and not as an action motivated by desire for power and control), which may lead individuals to believe that features like the victim's appearance are relevant when assessing a crime of this nature (Anderson \& Swainson, 2001). In light of this perspective, individuals consider this crime as the result of the offender's innate sexual desire, and the responsibility for controlling these desires depends on women; thus, they is expected to accept the consequence of the his lack of control (Coates \& Wade, 2001). These sort of beliefs lead to the absolution of the perpetrator, because he is believed not to have control over his actions (Coates \& Wade, 2004; Feild, 1979).

Likewise, men express greater acceptance of rape myths (Vrij \& Firmin, 2001), assign more blame (Deitz et al., 1984; Thornton \& Ryckman, 1983; Vrij \& Firmin, 2001), and identify less with the victim and more with the offender (Deitz et al., 1984; Vrij \& Firmin, 2001). They express less certainty about the perpetrator's guilt (Deitz et al., 1984) and have more sexist beliefs than women (Aosved \& Long, 2006). So, it is important to consider the role of gender when studying the social perception of rape.

\section{Overview and hypotheses}

At least two points emerge from the reasoning outlined above: (1) individuals with large eyes (a neotenous feature) are perceived more positively (Geldart et al., 1999; Gonçalves et al., 2012a; Paunonen et al., 1999); and (2) observer gender might be a significant element of rape perception, since this is a gendered crime (Gölge et al., 2003; Newcombe et al., 2008) and individuals usually hold more favourable attitudes towards in-group members, namely based on gender (Tajfel et al., 1971; Tajfel \& Turner, 1986).

Therefore, the current study examined the effect of eye size and observer gender on attributions of responsibility. The effect of eye size and gender on initial attraction and perceived honesty was also analysed. The following hypotheses were developed and tested: (1) the stimulus with large eye size will be perceived as more (a) attractive and (b) honest; (2) the female stimulus will be considered more attractive by men than by women; (3) women will consider the female stimulus more honest than men; (4) when the victim has large eyes, she will be held less responsible and the offender will be assigned more responsibility; (5) women will perceive the victim as less responsible and men will see the perpetrator as less responsible.

\section{Method}

\section{Design and participants}

A 3 (eye size: small vs. normal vs. large) x 2 (observer gender: female vs. male) between-subjects design was used, with four dependent variables: initial attraction, perceived honesty, rape victim and perpetrator responsibility. A convenience sample with a total of 90 participants (45 women and 45 men) participated in this study. Participants ranged from 18 to 57 years, with a mean age of $26.87\left(M_{\text {(female) }}=\right.$ $\left.26.07, S D=7.96 ; M_{\text {(male })}=26.67, S D=7.89\right)$, and were randomly assigned to one of six conditions $(n=15)$ (according to their gender and the stimulus eye size). No statistically significant differences $(p>.05)$ for age were found among groups, all the participants were Portuguese, most were single $(74 \%)$, and had 12 years of schooling $(58 \%)$.

\section{Measures and materials}

A picture with an average-looking female face was selected in order to manipulate eye size. The manipulation decreased/increased the eye size by $20 \%$. This procedure was conducted by an image manipulation expert using free software GIMP. The picture was presented to participants as a $13 \times 9 \mathrm{~cm}$ portrait (in colour).

The rape scenario (appendix 1) describes a traditional victim (housewife) being driven home by a colleague after a dinner at her singing school. He made advances towards the victim while they were alone in a car on a deserted road. The victim refused the advances and pushed the perpetrator, but he forced himself on her and completed the rape.

A self-report questionnaire was used in the study and participants were initially presented with questions about initial attraction and perceived honesty regarding the female stimulus. They were then asked to read the rape scenario and to rate the victim and rapist responsibility. The following measures were used: (a) Initial Attraction Index (IAI, Rodrigues \& Garcia-Marques, 2006), which consists of 31 items $(a=.97)$ with a 7 -point response scale $(1=$ nothing to 7 $=a(0 t), 9$ items assessing willingness to interact / positivity (e.g. "I feel interested"; $a=.94), 7$ items assessing physiological reactions (e.g.; "I feel butterflies in my stomach"; $a=.90$ ), and 15 items assessing flirting behaviour / fantasy (I feel curiosity"; a $=.91)-$ reliabilities of the current sample for the overall scale and subscales were $0.98,0.93,0.91$, and 0.96 , respectively; b) Honesty Scale (HS, Reysen, 2008), which is composed of 8 items (e.g., "This person is honest"; $a=.89$ ) scored in a 7 -point scale $(1=$ strongly disagree to $7=$ strongly agree $)-$ this scale was translated to Portuguese by bilingual specialists using the back translation method, and it was re-evaluated by field experts $(a=.85)$; c) perceptions of the rape victim (VR) and perpetrator responsibility (PR) (after reading the rape scenario and imagining the victim was the female in the picture). These perceptions were assessed with the Rape Responsibility Scale, a 14-item scale (e.g., "Maria / José is 
responsible for the situation") developed by the authors (appendix 2), using a 7 -point scoring $(1=$ nothing to $7=a$ lot $)$. Two items were reverse-scored so that higher scores indicated higher responsibility for all items.

Socio-demographic information included gender, age, nationality, education level and marital status. The questionnaire further comprised three control questions asking participants to identify the aim of the study and if they had been rape victims or knew any rape victim (results showed that this was not the case). A complete questionnaire pretest was conducted in a sample of 24 individuals, which led to minor adjustments before the final version.

\section{Procedure}

Participants were approached in several settings (e.g., classrooms, cafés, libraries, public streets, and other public places), being asked to participate in a study about human behaviour (full disclosure of the objective could hinder the results of the study). Following informed consent procedures and the assurance of confidentiality of the disclosed data, respondents were randomly assigned to one of the three pictures and the questionnaire was applied individually, with an average duration of 15 minutes. Upon completing the questionnaire, participants were fully debriefed on the specific goal of the study, and additional information was given when requested

\section{Results}

\section{Initial attraction and honesty}

Mean scores and standard deviations for initial attraction and honesty measures (by condition) are displayed in Table 1. Honesty presents an overall mean score slightly above the central point $(M=4.43)$, whereas initial attraction with the female stimulus is shown to have low scores $(M=2.32)$.

Table 1. Mean scores and standard deviations for attraction and honesty (by condition).

\begin{tabular}{|c|c|c|c|c|c|c|c|c|c|}
\hline & \multirow[b]{3}{*}{ Gender } & \multicolumn{8}{|c|}{ Eye Size } \\
\hline & & \multicolumn{2}{|c|}{ Small } & \multicolumn{2}{|c|}{ Normal } & \multicolumn{2}{|c|}{ Large } & \multicolumn{2}{|c|}{ Total } \\
\hline & & $M$ & $S D$ & $M$ & $S D$ & $M$ & $S D$ & $M$ & $S D$ \\
\hline \multirow[t]{3}{*}{ Attraction } & Female & 1.90 & 1.02 & 1.59 & 0.62 & 2.20 & 0.95 & 1.90 & 0.89 \\
\hline & Male & 2.10 & 0.90 & 2.83 & 1.46 & 3.32 & 1.44 & 2.75 & 1.36 \\
\hline & Total & 2.00 & 0.95 & 2.21 & 1.27 & 2.76 & 1.32 & 2.32 & 1.22 \\
\hline \multirow[t]{3}{*}{ Honesty } & Female & 3.97 & 0.64 & 4.35 & 0.93 & 4.70 & 0.80 & 4.34 & 0.84 \\
\hline & Male & 4.35 & 1.13 & 4.32 & 0.71 & 4.89 & 0.97 & 4.52 & 0.97 \\
\hline & Total & 4.16 & 0.92 & 4.33 & 0.81 & 4.80 & 0.88 & 4.43 & 0.90 \\
\hline
\end{tabular}

A one-way analysis of variance (ANOVA) was calculated on participants' ratings of initial attraction for a 3 (eye size: small vs. normal vs. large) X 2 (observer gender: female vs. male) between-subjects experiment. Main effects of eye size $\left(F_{(2,84)}=3.787, p=.027, \mu_{p}^{2}=.083\right)$ and gender $\left(F_{(1,84)}=\right.$ $\left.13.413, p<.001, \mu_{p}^{2}=.138\right)$ were observed, but no interaction effect $\left(F_{(2,84)}=1.958, p=.148, \mu_{p}^{2}=.045\right)$ was found. Tukey post-hoc tests (with $a=.05$ ) indicate significant differences between the large and small eye size $(p=.025)$ : the female with small eyes $(M=2.00)$ is considered less attractive than the one with large eyes $(M=2.76)$. With reference to gender, male participants $(M=2.75)$ report greater attraction for the stimulus than the female participants $(M=1.90)$. Initial attraction subscales follow the same pattern observed for the overall scale, with the same effect of eye size and gender $(p<.05)$.

The same effect of eye size was found for perceived honesty $\left(F_{(2,84)}=4.226, p=.018, \mu_{p}^{2}=.091\right)$; however, neither gender $\left(F_{(1,84)}=.952, p=.332, \mu_{p}^{2}=.011\right)$ nor interaction effects $\left(F_{(2,84)}=.424, p=.656, \mu_{p}^{2}=.010\right)$ were observed. Tukey HSD test shows a significant difference between the large and small eye size $(p=.017)$ : the female with large eyes $(M=4.43)$ is seen as more honest than the one with small eyes $(M=4.16)$.

\section{Rape Responsibility Scale: Exploratory factor analy-} sis

The factor structure of the Rape Responsibility Scale (originally developed for the purpose of this study) was analyzed through reliability and exploratory factor analyses. The KMO value of the data was .78 and the Bartlett's test was significant $\left(\chi^{2}=1413.503 ; D F=78\right.$; $\left.p<.001\right)$. All the communalities were higher than 0.30 (between 0.32 and 0.69 ) and no items were dropped from the analysis.

The exploratory factor analysis, using the principal components estimation method with varimax rotation and the criterion of eigenvalue higher than 1.00 , produced a twofactor solution accounting for $52.82 \%$ of the total variance (37.93\% for Factor 1 and $14.89 \%$ for Factor 2). Both factors were identified, respectively, as Victim Responsibility and Perpetrator Responsibility, with eigenvalues of 5.31 and 2.08. The standardized factor loadings for the 14 items composing these two factors are presented in Table 2. 
Table 2. Factor Loadings for the 14 Items of the Rape Responsibility Scale.

\begin{tabular}{ccc}
\hline Item & $\begin{array}{c}\text { Factor 1 } \\
\text { (Victim Responsibility) }\end{array}$ & $\begin{array}{c}\text { Factor 2 } \\
\text { (Perpetrator Responsibility) }\end{array}$ \\
\hline VR1 & 0.81 & \\
VR2 & 0.55 & \\
VR3 & 0.55 & \\
VR4 & 0.45 & \\
VR5 & 0.79 & \\
VR6 & 0.83 & \\
VR7 & 0.78 & \\
PR1 & & 0.64 \\
PR2 & & 0.59 \\
PR3 & & 0.74 \\
PR4 & & 0.57 \\
PR5 & & 0.82 \\
PR6 & & 0.71 \\
PR7 & & 0.73 \\
\hline Variance $(\%)$ & 37.93 & 14.89 \\
Reliability $(\alpha)$ & 0.84 & 0.79 \\
\hline
\end{tabular}

As seen in Table 2, the results regarding reliability further indicate that both factors present acceptable internal consistency $\left(a_{(\mathrm{RV})}=0.84 ; a_{(\mathrm{PR})}=0.79\right)$. Concurrent validity was found via correlational tests between RV and PR, with a moderate negative relation being found between both dimensions $(r=-.49, p<.001)$.

\section{Attributions of responsibility for rape}

Mean scores and standard deviations for attributions of responsibility (victim and perpetrator) by condition are shown in table 3 . Overall, the victim is not assigned much responsibility $(M=2.65)$, whereas the rapist is held quite responsible for the situation $(M=5.67)$.

Eye size $\left(F_{(2,84)}=18.341, p<.001, \mu_{p}^{2}=.304\right)$ and observer gender $\left(F_{(1,84)}=4.153, p=.045, \mu_{p}^{2}=.067\right)$ were shown to influence the victim responsibility, but no interaction effect $\left(F_{(2,84)}=9.021, p<.001, \mu_{p}^{2}=.047\right)$ was found. Statistically significant differences for large eye size in relation to normal $(p<.001)$ and small eye size $(p<.001)$ were reported by using a Tukey post-hoc test for multiple comparisons: the victim with large eyes is assigned less responsibility $(M=1.83)$ than the one with normal $(M=3.02)$ and small eyes $(M=3.11)$. Regarding gender, men $(M=2.85)$ held the victim more responsible than women $(M=2.46)$.

Table 3. Descriptive statistics for attributions of responsibility, according to condition.

\begin{tabular}{|c|c|c|c|c|c|c|c|c|c|}
\hline \multirow[b]{3}{*}{ Dependent variable } & \multirow[b]{3}{*}{ Gender } & \multicolumn{8}{|c|}{ Eye Size } \\
\hline & & \multicolumn{2}{|c|}{ Small } & \multicolumn{2}{|c|}{ Normal } & \multicolumn{2}{|c|}{ Large } & \multicolumn{2}{|c|}{ Total } \\
\hline & & $M$ & $S D$ & $M$ & $S D$ & $M$ & $S D$ & $M$ & $S D$ \\
\hline \multirow{3}{*}{ Victim responsibility } & Female & 2.60 & 0.94 & 2.89 & 1.05 & 1.89 & 0.93 & 2.46 & 1.04 \\
\hline & Male & 3.63 & 1.00 & 3.15 & 0.93 & 1.77 & 0.56 & 2.85 & 1.15 \\
\hline & Total & 3.11 & 1.09 & 3.02 & 0.99 & 1.83 & 0.76 & 2.65 & 1.11 \\
\hline \multirow{3}{*}{ Perpetrator responsibility } & Female & 5.43 & 1.07 & 5.78 & 0.75 & 6.24 & 0.51 & 5.82 & 0.86 \\
\hline & Male & 5.00 & 105 & 5.50 & 0.96 & 6.10 & 0.60 & 5.53 & 0.98 \\
\hline & Total & 5.21 & 1.06 & 5.64 & 0.86 & 6.17 & 0.55 & 5.67 & 0.93 \\
\hline
\end{tabular}

In reference to perpetrator responsibility, a main effect of eye size was observed $\left(F_{(2,84)}=9.513, p<.001, \mu_{\mathrm{p}}^{2}=\right.$ $.185)$, but no gender $\left(F_{(1,84)}=2.476, p=.119, \mu_{p}^{2}=.029\right)$ nor interaction effect $\left(F_{(2,84)}=.225, p=.799, \mu_{p}^{2}=.005\right)$ were found. Tukey post-hoc test reports significant differences for the large eye size in comparison to the normal $(p=.045)$ and the small eye size $(p<.001)$. Descriptive statistics confirms that, in comparison with the normal $(M=5.64)$ and small eyes $(M=5.21)$ conditions, participants held the offender more responsible when the victim presented large eyes $(M=6.17)$

\section{Discussion and conclusion}

The current study examined the effect of eye size and observer gender on initial attraction, perceived honesty, and attributions of responsibility for rape. Overall, the results obtained are consistent with the underlying theory.
The role of eye size and observer gender on initial attraction and honesty

The first research hypothesis was confirmed, with eye size influencing (a) initial attraction and (b) perceived honesty: the female with large eyes is considered more attractive and honest. These results support the idea that individuals with large eyes have a social advantage, because this facial trait functions as a heuristic for the inference of positive attributes (Keating, Randall, Kendrick, \& Gutshall, 2003; Pettijohn \& Tesser, 2005). These results are reinforced by evidence that adults are more likely to find women with neotenous facial features, especially large eyes, more attractive (e.g., Cunningham et al., 1995; Geldart et al., 1999; Gonçalves et al., 2012a; Pettijohn \& Tesser, 2005). Human morphological development also supports the universality of this sort of perceptions (Keating et al., 2003). Human eyes become smaller with age and function as a heuristic for maturity (e.g., dominance or independence), whereas large eyes evoke youth traits (related to dependency, naivety or honesty). Hence, women with this trait are believed to be more attractive, young, and fertile (Cunningham et al., 1995; Wade, 
2010). Similarly, the female with larger eyes is perceived as more honest, which is consistent with other studies (e.g., AlAtoum \& Simadi, 2000; Keating et al., 2003; Paunonen et al., 1999; Zebrowitz, Voinescu, \& Collins, 1996). These outcomes seem to be based on the assumption that baby-faced adults personify traits of goodness and ingenuity (Zebrowitz et al., 1996).

The second research hypothesis was also supported, given that the observer gender has a main effect on initial attraction: men found the female stimulus more attractive than women. These gender differences may be related to biological and cultural factors (Gangestad, Hasselton, \& Buss 2006; Griffin \& Langlois, 2006), leading to a greater capacity to experience attraction for individuals of the opposite gender (Rodrigues \& Garcia-Marques, 2005). Additionally, the factor structure of the scale suggests the existence of two dimensions of attraction (i.e., physiological reactions and flirting behaviour) sexually oriented and typically associated with feelings towards the opposite gender.

Regarding the influence of gender on perceived honesty, as individuals usually have more favourable attitudes towards in-group members (Tajfel et al., 1971; Tajfel \& Turner, 1986), women were expected to score higher on this variable. However, the observer gender has no effect on perceived honesty, lending no support for our third research hypothesis. One explanation for these results might be related to the methodological procedures adopted or to the absence of real social interaction and other cues (verbal and nonverbal) that might have helped respondents to evaluate the female stimulus. In addition, facial features (e.g., eye size) might have been rather prevailing than social projection. Nonetheless, our results are supported by Atoum and Al-Simadi (2000), who found no gender differences concerning honesty judgments, even using different stimuli presentation modality (including video format).

\section{The influence of eye size and observer gender on at- tributions of responsibility}

Regarding the influence of eye size on attributions of responsibility for rape, the manipulation of this facial trait seems to result in different perceptions of both parties involved in a rape (victim and perpetrator). The victim was held less responsible and the offender was assigned more responsibility when the victim presented large eyes, lending support for our fourth research hypothesis.

As reasoned, physical appearance influences social perception and some traits are assumed to be more significant when judging others (Atoum \& Al-Simadi, 2000; Dion et al., 1972). Therefore, supposing the eyes are the focus of attention in facial perception (Argyle, 1970), this trait is thought to be important when judging a rape victim, underlining the idea that large eyes lead to more positive evaluations (Geldart et al., 1999; Gonçalves et al., 2012a). Individuals with neotenous features are also perceived as more naïve and trustworthy, provoking paternalistic and protective attitudes (e.g., Cunningham et al., 1995; Keating \& Doyle, 2002; Wade, 2010; Zebrowitz, Voinescu, \& Collins, 1996). Thus, the occurrence of events that put a woman with those attributes in a vulnerable situation (as the one described in the scenario used) allows respondents to assume that she was not responsible for her own faith.

Finally, the fifth research hypothesis was partially confirmed, because women attribute less responsibility to the victim, but there is no effect of gender on perpetrator responsibility (although, in general, the offender is held less responsible by men). Moreover, the victim was assigned little responsibility when compared to the perpetrator (by both women and men), which indicates a more favourable predisposition towards the rape victim. This trend of response may be based either on a feeling of closeness to the victim or on a perceived lack of moral responsibility, given that there is no evidence for a voluntary or intentional behaviour underlying rape (Schneider, Mori, Lambert, \& Wong, 2009).

As the victim is assigned less responsibility by women, gender was shown to have an effect on dispositional judgments regarding the victim. This was expected, because people typically hold more favourable attitudes towards ingroup members (Tajfel et al., 1971; Tajfel \& Turner 1986). Shaver's (1970) defensive attribution hypothesis further posits that blame attributions depend on the perceived similarity with the victim and the likelihood of similar victimization (thus motivating people to avoid future blame attributions). In this sense, considering that women are more likely to perceive themselves as more similar to the victim and that women are usually the rape victims, they held the victim less responsible as a self-defence mechanism.

Our findings add to the evidence that men assign more responsibility and blame to rape victims (e.g., Cohn et al., 2009; Deitz et al., 1984; Gölge et al., 2003; Mitchell, Angelone, Kohlberger, \& Hirschman, 2009; Workman \& Freeburg 1999), providing no support for past findings which reported no gender differences concerning attributions of responsibility (Davies, Gilston, \& Rogers, 2012; Frese, Moya, \& Megías, 2004; Gerdes et al., 1988; Krahè, 1988; Johnson et al., 1989).

Concerning offender attributions of responsibility, no significant gender differences were observed (he is assigned less responsibility by men, but these differences are not statistically significant). One possible explanation lies on the perceived seriousness and unambiguity of the situation, which might have reduced the impact of in-group biases (the inclusion of these measures is recommended in future studies). Ambiguity seems to be a central factor when explaining gender differences in rape perceptions, with men perceiving the ambiguous rape as more consensual than women (Humphreys, 1993). These data are supported by studies suggesting the importance of perceptual ambiguity on attributions of responsibility (e.g., Jacobson \& Popovich, 1983; Johnson et al., 1989). In real rape situations, observers are also given more information and there seems to be an increasing awareness of both females and males regarding the causes 
and consequences of rape, mostly because mass media have a strong social and cultural impact upon society. Keeping people informed and showing the victim's perspective are effective means to lessen stigma, regardless of gender.

\section{Implications, limitations and future directions}

Eye size was shown to influence both the perception of positive traits and attributions of responsibility. This represents a theoretical advance, as it sheds light on the effect of a specific facial trait on rape perceptions and supports the idea that eye size may function as a heuristic for social judgments. This study further shows that gender differences are important when regarding initial attraction and victim's assignments of responsibility. Given that the negative connotations related to rape may reduce the likelihood of reporting the crime, a thorough knowledge of the social stigma attached to this sort of phenomenon is paramount to design intervention programs focused on the general community, intervening institutions, and rape victims. Methodologies with greater ecological validity (and with the interpretation of real-world scenarios) should also be considered, in order to expand on the reported findings, and real actors and observers should be approached. The use of research action plans and the beliefs of professionals in contact with rape victims should further be considered (e.g., law enforcement officers, educators and health professionals).

\section{References}

Abrams, D., Viki, G. T., Masser B., \& Bohner, G. (2003). Perceptions of stranger and acquaintance rape: The role of benevolent and hostile sexism in victim blame and rape proclivity. Journal of Personality and Social Psychology, 84(1), 111-125. doi: 10.1037/0022-3514.84.1.111.

Acock, A. C., \& Ireland, N. K. (1983). Attribution of blame in rape cases: The impact of norm violation, gender, and sex-role attitude. Sex Roles, 9(2), 179-193. doi: 10.1007/BF00289622.

Ambady, N. \& Skowronski, J.J. (Eds.) (2008). First impressions. New York: Guilford Press.

Anderson, I., \& Swainson, V. (2001). Perceived motivation for rape: Gender differences in beliefs about female and male rape. Current Research in Social Psychology, 6(8), 107-123.

Anderson, L. A., \& Whiston, S. C. (2005). Sexual assault education programs: A meta-analytic examination of their effectiveness. Psychology of Women Quarterly, 29(4), 374-388. doi: 10.1111/j.1471-6402.2005.00237.x.

Angelone, D. J., Mitchell, D., \& Lucente, L. (2012). Predicting perceptions of date rape: An examination of perpetrator motivation, relationship length, and gender role beliefs. Journal of Interpersonal Violence, 20(20), 1 21. oi: $10.1177 / 0886260512436385$.

Aosved, A. C., \& Long, P. J. (2006). Co-occurrence of rape myth acceptance, sexism, racism, homophobia, ageism, classism, and religious intolerance. Sex Roles, 55(7-8), 481-492. doi: 10.1007/s11199-006-91014.

Argyle, M. (1970). Eye-contact and distance: a reply to Stephenson and Rutter. British Journal of Psychology, 61(3), 395-396. doi: 10.1111/j.20448295.1970.tb01258.x.

Atoum, A. O., \& Al-Simadi, F. A. (2000). The effect of presentation modality on judgments of honesty and attractiveness. Social Behavior and Personality, 28(3), 269-278. doi: 10.2224/sbp.2000.28.3.269.

Best, J. B., \& Demmin, H. S. (1982). Victim's provocativeness and victim's attractiveness as determinants of blame in rape. Psychological Reports, 51(1), 255-258. doi: 10.2466/pr0.1982.51.1.255.
As aforementioned, one limitation acknowledged in the current study is the absence of an ambiguous scenario, which might have affected our results. This should be considered in future research, through the use of an ambiguous scenario, a strange rapist and a non-traditional woman. The inclusion of descriptions in video format and of measures to assess the perception of the situation as a rape (as well as its seriousness) should also be included. Future studies, with larger samples, are further required to contemplate sexual orientation and other variables associated to gender attitudes (e.g., ambivalent sexism or neosexism), in that they may predict value orientations and affect the results.

The analysis of the psychological constructs related rape perceptions deserves more attention, given that attributions of responsibility for rape are complex and involve sexist beliefs about gender roles, rape myths, empathy, and other variables. The testing of predictive models regarding the theoretical concepts above-mentioned (and others) should also be considered along with assignments of blame to rape victims and perpetrators. As a closing suggestion, the impact of cultural values on rape perceptions, as well as the comparison between male and female rape victims, should also be addressed in future research.

Acknowledgments.- This research was partially financed by the Foundation for Science and Technology (Portugal).

Capezza, N. M., \& Arriaga, X. B. (2008). Why do people blame victims of abuse? The role of stereotypes of women on perceptions of blame. Sex Roles, 59(11), 839-850. doi: 10.1007/s11199-008-9488-1.

Coates, L., \& Wade, A. (2004). Telling it like it isn't: Obscuring perpetrator responsibility for violent crime. Discourse \& Society, 15(5), 499-526. doi: 10.1177/0957926504045031.

Cohn, E. S., Dupuis, E. C., \& Brown, T. M. (2009). In the eye of the beholder: Do behavior and character affect victim and perpetrator responsibility for acquaintance rape? Journal of Applied Social Psychology, 39(7), 1513-1535. doi: 10.1111/j.1559-1816.2009.00493.x.

Cunningham, M. R., Roberts, A. R., Barbee, A. P., Druen, P. B., \& Wu, C. (1995). "Their ideas of beauty are, on the whole, the same as ours": Consistency and variability in the cross-cultural perception of female physical attractiveness. Journal of Personality and Social Psychology, 68(2), 261-279. doi: 10.1037/0022-3514.68.2.261.

Davies, M., Gilston, J., \& Rogers, P. (2012). Examining the relationship between male rape myth acceptance, female rape myth acceptance, victim blame, homophobia, gender roles, and ambivalent sexism. Journal of Interpersonal Violence, 27(14), 2807-2823. doi: 10.1177/0886260512438281.

Deitz, S. R., Littman, M., \& Bentley, B. J. (1984). Attribution of responsibility for rape: The influence of observer empathy, victim resistance, and victim attractiveness. Sex Roles, 10(3-4), 261-280. doi:10.1007/BF00287780.

DeJong, W. (1999). Rape and physical attractiveness: Judgments concerning likelihood of victimization. Psychological Reports, 85(1), 32-34. doi: 10.2466/pr0.1999.85.1.32.

Dion, K., Berscheid, E., \& Walster, E. (1972). What is beautiful is good. Journal of Personality and Social Psychology, 24(3), 285-290. doi: $10.1037 / \mathrm{h} 0033731$.

Erian, M., Lin, C., Patel, N., Neal, A., \& Geiselman, R. E. (1998). Juror verdicts as a function of victim and defendant attractiveness in sexual assault cases. American Journal of Forensic Psychology, 16(3), 25-40. 
Feild, H. S. (1979). Rape trials and jurors' decisions: A psycholegal analysis of the effects of victim, defendant, and case characteristics. Law and Human Behavior, 3(4), 261-284. doi: 10.1007/BF01039806.

Frese, B., Moya, M., \& Megías, J. L. (2004). Social perception of rape: How rape myth acceptance modulates the influence of situational factors. Journal of Interpersonal Violence, 19(2), 143-161. doi: $10.1177 / 0886260503260245$.

Fiske, S. T., Cuddy, A. J. C., Glick, P., \& Xu, J. (2002). A model of (often mixed) stereotype content: Competence and warmth respectively follow from perceived status and competition. Journal of Personality and Social Psychology, 82(6), 878-902. doi: 10.1037//0022-3514.82.6.878.

Gangestad, S. W., Haselton, M. G., \& Buss, D. M. (2006). Evolutionary foundations of cultural variation: Evoked culture and mate preferences. Psychological Inquiry, 17(2), 75-95. doi: 10.1207/s15327965pli1702_1.

Geldart, S., Maurer, D., \& Carney, K. (1999). Effects of eye size on adults' aesthetic ratings of faces and 5-month-olds' looking times. Perception, 28(3), 361-374. DOI: 10.1016/S0163-6383(98)91640-X.

Gerdes, E. P., Dammann, E. J., \& Heilig, K. E. (1988). Perceptions of rape victims and assailants: Effects of physical attractiveness, acquaintance, and subject gender. Sex Roles, 19(3-4), 141-153. doi: 10.1007/BF00290151.

Gölge, Z. B., Yavuz, M. F., Müderrisoglu, S., \& Yavuz, M. S. (2003). Turkish university students' attitudes toward rape. Sex Roles, 49(11-12), 653-661. doi: 10.1023/B:SERS.0000003135.30077.a4.

Gonçalves, G., Martins, A. T., Parreira, T., Ferrão, M. C., Santos, J. V., Giger, J-C., \& Gomes, A. (2012a). The eye size has an influence in the way we judge others. In C. Sousa \& A. M. Oliveira (Eds.), Proceedings of the 14th European Conference on Facial Expression: New Challenges for Research (pp.121-128). Lisboa/Almada: European Society for the Study of Facial Expressions/IPCDVS.

Gonçalves, G., Martins, A. T., Ferrão, M. C., Parreira, T., Gomes, A., \& Ramos, A-O. (2012b). People judge a book through its cover and humans by their eyes. International Journal of Advances in Social Psychology, 1(2), 40-45.

Gonçalves, G., Gomes, A., Ferrão, M. C., Parreira, T., Santos, J. V., Giger, JC., \& Martins, A. T. (2014). Once upon a face: The effect of eye size, observer gender and stimulus gender on impression formation. Current Psychology (published online 07/2014). doi: 10.1007/s12144-014-9244-3.

Griffin, A. M. \& Langlois, J. H. (2006). Stereotype directionality and attractiveness stereotyping: Is beauty good or is ugly bad? Social Cognition, 24(2), 212-246. doi: 10.1521/soco.2006.24.2.187.

Gregory, J., and Lees, S. (1999). Policing Sexual Assault. London: Routledge.

Grubb, A. R., \& Harrower, J. (2009). Understanding attribution of blame in cases of rape: An analysis of participant gender, type of rape and perceived similarity to the victim. Journal of Sexual Aggression, 15(1), 63-81. doi:10.1080/13552600802641649.

Grubb, A. R., \& Turner, E. (2012). Attribution of blame in rape cases: A review of the impact of rape myth acceptance, gender role conformity and substance use on victim blaming. Aggression and Violent Behavior, 17(5), 443-452. doi: 10.1016/j.avb.2012.06.002.

Humphreys, T. P. (1993). Gender Differences in the Perception of Rape: The Role of Ambiguity [Thesis submitted to the Department of Psychology of the Wilfrid Laurier University in partial fulfillment of the requirements for the Master of Arts Degree]. Ontario: Wilfrid Laurier University.

Jacobson, M. B., \& Popovich, P. M. (1983). Victim attractiveness and perceptions of responsibility in an ambiguous rape case. Psychology of Women Quarterly, 8(1), 100-104. doi: 10.1111/j.1471-6402.1983.tb00621.x.

Johnson, J. D., Jackson, L. A. \& Smith, G. J. (1989). The role of ambiguity and gender in mediating the effects of salient conditions. Personality and Social Psychology Bulletin, 15(1), 52-60. doi: 10.1177/0146167289151005.

Keating, C. F., \& Doyle, J. (2002). The faces of desirable mates and dates contain mixed social status cues. Journal of Experimental Social Psychology, 38(4), 414-424. doi: 10.1016/S0022-1031(02)00007-0

Keating, C. F., Randall, D. W., Kendrick, T., \& Gutshall, K. A. (2003). Do babyfaced adults receive more help? The (cross-cultural) case of the lost resume. Journal of Nonverbal Behavior, 27(2), 89-109. doi: 10.1023/A:1023962425692.

Kelly, L. (2002). A Research Review on the Reporting, Investigation and Prosecution of Rape Cases. London: HMCPSI.
Kościński, K. (2007). Facial attractiveness: General patterns of facial preferences. Anthropological Review, 70(1), 45-79. doi: 10.2478/v10044-0080001-9.

Krahè, B. (1991). Social psychological issues in the study of rape. European Review of Social Psychology, 2(1), 279-309. doi: 10.1080/14792779143000097.

Krahè, B. (1988). Victim and observer characteristics as determinants of responsibility attributions to victims of rape. Journal of Applied Social Psychology, 18(1), 50-58. doi: 10.1111/j.1559-1816.1988.tb00004.x.

Langlois, J. H., Kalakanis, L., Rubenstein, A. J., Larson, A., Hallam, M., \& Smoot, M. (2000). Maxims or myths of beauty? A meta-analytic and theoretical review. Psychological Bulletin, 126(3), 390-423. doi: 10.1037/0033-2909.126.3.390.

Langlois, J. H., Ritter, J. M., Roggman, L. A., \& Vaughn, L. S. (1991). Facial diversity and infant preferences for attractive faces. Developmental Psychology, 27(1), 79-84. doi: 10.1037/0012-1649.27.1.79.

Luginbuhl, J., \& Mullin, C. (1981). Rape and responsibility: How and how much is the victim blamed? Sex Roles, 7(5), 547-559. doi: $10.1007 / \mathrm{BF} 00288631$.

Mitchell, D., Angelone, D. J., Kohlberger, B., \& Hirschman, R. (2009). Effects of offender motivation, victim gender, and participant gender on perceptions of rape victims and offenders. Journal of Interpersonal Violence, 24(9), 1564-1578. doi: 10.1177/0886260508323662.

Moore, F. R., Filippou, D., \& Perrett, D. I. (2011). Intelligence and attractiveness in the face: Beyond the attractiveness halo effect. Journal of Evolutionary Psychology, 9(3), 205-217. doi: 10.1556/JEP.9.2011.3.2.

Nagel, B., Matsuo, H., McIntyre, K. P., \& Morrison, N. (2005). Attitudes toward victims of rape: Effects of gender, race, religion, and social class. Journal of Interpersonal Violence, 20(6), 725-737. doi: $10.1177 / 0886260505276072$.

Newcombe, P. a., van den Eynde, J., Hafner, D., \& Jolly, L. (2008). Attributions of responsibility for rape: Differences across familiarity of situation, gender, and acceptance of rape myths. Journal of Applied Social Psychology, 38(7), 1736-1754. doi: 10.1111/j.1559-1816.2008.00367.x

Paunonen, S. V., Ewan, K., Erathy, J., Lefave, S., \& Goldberg, H. (1999). Facial features as personality cues. Journal of Personality, 67(3), 555-583. doi: 10.1111/1467-6494.00065.

Pettijohn, T. F. II, \& Tesser, A. (2005). Threat and social choice: When eye size matters. The Journal of Social Psychology, 145(5), 547-570. doi: 10.3200/SOCP.145.5.547-570.

Pollard, P. (1992). Judgments about victims and attackers in depicted rapes: A review. British Journal of Social Psychology, 31(4), 307-326. doi 10.1111/j.2044-8309.1992.tb00975.x.

Rebeiz, M. J., \& Harb, C. (2010). Perceptions of rape and attitudes toward women in a sample of Lebanese students. Journal of Interpersonal Violence 25(4), 735-752. doi: 10.1177/0886260509334410.

Reysen, S. (2008). Construction and validation of measures of perceived honesty and perceived expertise. Poster presented at the 54th Annual Meeting of the Southwestern Psychological Association. Kansas City, MO.

Rodrigues, D. \& Garcia-Marques, T. (2006). Como medir a atracção sentida num primeiro encontro? Propriedades métricas do Indice de Atracção Inicial (IAI). VT Simpósio Nacional de Investigação em Psicologia. Évora.

Rodrigues, D. \& Garcia-Marques, T. (2005). Marquemos o encontro ao cimo da escada: O papel da activação fisiológica na atracção interpessoal. Análise Psicológica, 23(4), 427-436.

Schneider, L. J., Mori, P. L. L., \& Wong, A. O. (2009). The role of gender and ethnicity in perceptions of rape and its aftereffects. Sex Roles, 60(5), 410-421. doi: 10.1007/s11199-008-9545-9.

Seligman, C., Brickman, J., \& Koulack, D. (1977). Rape and physical attractiveness: Assigning responsibility to victims. Journal of Personality, 45(4), 554-563. doi: 10.1111/j.1467-6494.1977.tb00171.x.

Shaver, K. G. (1970). Defensive attribution: Effects of severity and relevance on the responsibility assigned for an accident. Journal of Personality and Social Psychology, 14(2), 101-113. doi: 10.1037/h0028777.

Shinners, E. (2009). Effects of the "what is beautiful is good" stereotype on perceived trustworthiness. UW-L Journal of Undergraduate Research, 12, 1

Tajfel, H., Billig, M. G., Bundy, R. P., \& Flament, C. (1971). Social categorization and inter-group behavior. European Journal of Social Psychology, 1(2), 149-178. doi:10.1002/ejsp.2420010202. 
Tajfel, H., \& Turner, J. C. (1986). The social identity theory of intergroup behavior. In S. Worchel \& W. G. Austin (eds.), Psychology of Intergroup Relations (2nd ed., pp. 7-24). Chicago: Nelson-Hall.

Tarsi, M. M., \& Jalbert, N. L. (1999). Observers' evaluations of couples involved in date rape. Psi Chi Journal of Undergraduate Research, 4(3), 119124.

Thornton, B., \& Ryckman, R. M. (1983). The influence of a rape victim's physical attractiveness on observers' attributions of responsibility. $\mathrm{Hu}$ man Relations, 36(6), 549-561. doi: 10.1177/001872678303600604.

Viki, G. T., \& Abrams, D. (2002). But she was unfaithful: Benevolent sexism and reactions to rape victims who violate traditional gender role expectations. Sex Roles, 47(5), 289-293. doi: 10.1023/A:1021342912248.

Vrii, A., \& Firmin, H. (2001). Beautiful thus innocent? The impact of defendants' and victims' physical attractiveness and participants' rape beliefs on impression formation in alleged rape cases. International Review of Victimology, 8(3), 245-255. doi: 10.1177/026975800100800301.
Wade, T. J. (2010). The Relationships between symmetry and attractiveness and mating relevant decisions and behavior: A review. Symmetry, 2(2), 1081-1098. doi: 10.3390/sym2021081.

Whatley, M. A. (2005). The effect of participant sex, victim dress, and traditional attitudes on causal judgments for marital rape victims. Journal of Family Violence, 20(3), 191-200. doi: 10.1007/s10896-005-3655-8.

Workman, J. E., \& Freeburg, E. W. (1999). An examination of date rape, victim dress, and perceiver variables within the context of attribution theory. Sex Roles, 41(3-4), 261-277. doi: 10.1023/A:1018858313267.

Zebrowitz, L. A., Voinescu, L., \& Collins, M. A. (1996). "Wide-eyed" and "crooked-faced": Determinants of perceived and real honesty across the life span. Personality and Social Psychology Bulletin, 22(12), 1258-1269. DOI: $10.1177 / 01461672962212006$.

(Article received: 12-11-2013; revised: 19-10-2014; accepted: 03-12-2014))

\section{Appendix 1 - Rape scenario}

Maria is a 32 year housewife, married for 5 years and with 2 children. One night, she went to a dinner at her singing school. A friend, Rita, gave her a ride to the restaurant, where everyone had a great time. Around midnight, Maria wanted to leave, but Rita wanted to stay a little longer. José, who had always been nice to her and whom she did some duets, offered to take her home. Along the way, they were telling jokes and laughing, when José said he wanted to show her a beautiful place. She said she preferred to go home, but he insisted and she said no more. José left the main road and stopped the car on a deserted road near a river with a bridge. When the car stopped, he looked at Maria and said he liked her. She was silent and he tried to kiss her. She refused, said she was married and she wanted to go home immediately. He kissed her neck and she continued to refuse. However, he started touching her thighs and between her legs. She shouted that she did not want and tried to push him away, but he continued to touch and kiss her. She kept screaming and begging him to stop, but he pulled her skirt up, pulled her underwear and penetrated her.

\section{Appendix 2 - Scale on attributions of responsibility for rape}

RV1 Se realmente quisesse, a Maria poderia ter-se defendido de forma mais eficaz (If Maria really wanted, she could have deffended more effectively).

RV2 A Maria comportou-se de forma sedutora com o José (Maria behaved seductively with Josê).

RV3 Na verdade, a Maria desejou ter relações sexuais com o José (In fact, Maria wanted to have sex with Josê).

RV4* A Maria fez tudo o que podia para evitar a situação (Maria did everything she could to avoid the situation).

RV5 Se a Maria tivesse sido mais convicta na sua recusa, nada disto teria acontecido (None of this would have happened if Maria had been more convinced of her refusal).

RV6 Se realmente quisesse, a Maria poderia ter fugido do carro (If Maria really wanted, she could have fled the car).

RV7 A Maria é responsável pela situação (Maria is responsible for the situation).

RA1 Se realmente quisesse, o José poderia ter evitado o seu comportamento (If José really wanted, he could have avoided his behavior).

RA2 A situação foi planeada pelo José desde que saíram do restaurante (The situation was planned by José since they left the restaurant).

RA3 O José queria ter relações sexuais a qualquer custo (José wanted to have sex at any cost).

RA4* O José apenas pretendeu ser simpático e levar a Maria a casa (José just pretended to be friendly and take Maria ho$m e)$.

RA5 O José forçou a Maria a ter relações sexuais (Joséforced Maria to have sex).

RA6 Isto só aconteceu porque o José é uma pessoa indecente (This only happened because José is an indecent person).

RA7 O José é responsável pela situação (José is responsible for the situation).

* Reverse-scored items. 